\title{
Article
}

\author{
Doi 10.5943/sif/6/1/3
}

\section{First record of Eutypella vitis causing branch dieback on new host trees in Canada}

\author{
Ilyukhin $\mathbf{E}^{1}$, Bulgakov $\mathbf{T}^{2}$, Markovskaja $\mathrm{S}^{3}$
}

\author{
${ }^{1}$ Department of Biological Sciences, Brock University, St. Catharines, Ontario, Canada \\ ${ }^{2}$ Department of Plant Protection, Federal Research Centre the Subtropical Scientific Centre of the Russian Academy of \\ Sciences, 2/28 Yana Fabritsiusa Street, Sochi 354002, Krasnodar region, Russia \\ ${ }^{3}$ Laboratory of Mycology, Nature Research Centre, LT 08406, Vilnius, Lithuania
}

Ilyukhin E, Bulgakov T, Markovskaja S 2021 - First record of Eutypella vitis causing branch dieback on new host trees in Canada. Studies in Fungi 6(1), 71-77, Doi 10.5943/sif/6/1/3

\begin{abstract}
Eutypella vitis is reported for the first time on several new host trees viz. Fagus grandifolia, Fraxinus pennsylvanica and Syringa reticulata with associated branch dieback symptoms in the Niagara Region of Southern Ontario, Canada. Morphological characteristics and phylogenetic analyses of ITS sequence data confirmed the species identification. Eutypella vitis is known as a woody plant pathogen causing dieback of grapevines and other economically important fruit trees widely cultivated in Ontario. The fungus ability to infect several alternate new hosts can promote its faster and wider spread across vineyards and consequently increase a dieback hazard to viticulture in Canada.
\end{abstract}

Key words - Diatrypaceae - Eutypa dieback - grapevines - multi-host plant pathogen

\section{Introduction}

Grapevine is considered as one of the economically important horticultural crops in Ontario. The provincial growers produced 77,775 tons of grapes with farm value of $\$ 111.2$ Mil in 2019 (OMAFRA). Some important fungal diseases and pathogens affecting grapevine yield are still poorly known in Canada, including trunk diseases.

The recent studies of grapevine diseases in British Columbia (Okanagan, Similkameen, Fraser valleys, and the Vancouver and Gulf islands) have revealed that the grapevine trunk diseases (GTD) are associated with fungal pathogens of Cadophora, Phaeomoniella, Phaeoacremonium and Togninia genera as well as with the cancer and dieback diseases caused by Botryosphaeria, Diaporthe and Eutypa species. These pathogenic fungi cause the diseases limiting both vineyard longevity and productivity in British Columbia (O'Gorman et al. 2013, Úrbez-Torres et al. 2014). The common dieback symptoms appear as branch stunting, leaf distortion and perennial cankers that can finely result in grapevine decline (Carter 1991, Úrbez-Torres et al. 2009).

One of the grapevine cankers and consequent dieback diseases, Eutypa dieback, is usually associated with Eutypa lata (E. lata) (Rolshausen et al. 2006). However, the recent reports show that different diatrypaceous fungi can cause Eutypa dieback: Eutypa leptoplaca (Trouillas \& Gubler 2004), Cryptovalsa ampelina (Luque et al. 2006) and E. vitis (Catal et al. 2007). The pathogen, E. vitis, was not previously reported from Ontario on grapevines as well as on other host plants. However, the fungus has been located in North America (Vasilyeva \& Stephenson 2006) and is known in adjacent Michigan State of the USA (Jordan \& Schilder 2005). E. vitis and other 
diatrypaceous fungi have been found to be pathogenic to grapevines in Texas, USA (Úrbez-Torres et al. 2009). It has also reported that the species is associated with branch dieback of Japanese persimmon trees (Diospyros kaki Thunb.) (Firoozjah et al. 2015) and Persian walnut trees (Juglans regia L.) in Iran (Sohrabi at al. 2020) indicating that these tree species as alternative hosts play the role of fungal inoculum's reservoirs that may contribute to the epidemiology of grapevine dieback.

For this reason, we surveyed the local forest stands in the Niagara region of Southern Ontario (Canada) to find any trees and shrubs with symptoms similar to Eutypa dieback. This kind of branch dieback was observed on several tree species (Fagus grandifolia Ehrh., Fraxinus pennsylvanica Marshall and Syringa reticulata (Blume) H. Hara)) in the studied area.

The main aim of this study was to isolate and identify the causative agent of the dieback on the trees growing in the region.

\section{Materials \& Methods}

The samples of affected branches were collected and single spore isolates were obtained following the method described in Phookamsak et al. (2015). The isolates were plated on malt extract agar (MEA, Seaweed Solution Laboratories, USA; $35 \mathrm{~g} / 1$ litre of sterile water) and incubated at room temperature $\left(20-25^{\circ} \mathrm{C}\right)$ in the dark. Germinating ascospores were aseptically transferred onto fresh MEA plates. Microscopic examinations, photomicrographs and measurements of 50 randomly selected spores from 3 different samples were taken with an AmScope B120C-E5 stereo microscope and AmScope SE306R-PZ dissecting microscope with a 5 MP digital AmScope camera MD500 supplied with AmScopeX software for Windows v4.8.15934 (AmScope, Irvine, USA). The voucher specimens were deposited into the Herbarium of the Nature Research Centre (BILAS), Institute of Botany, Vilnius, Lithuania. Facesoffungi number was registered for E. vitis as mentioned in Jayasiri et al. (2015).

DNA was extracted by performing a crude $\mathrm{NaOH}$ lysis on each colony (EI-13-ON, EI-109ON) picked. The internal transcribed spacer region (ITS) was amplified using primers ITS1/ITS4 (White et al. 1990) followed by enzymatic cleanup and sequenced using the BigDye Terminator v3.1 on an Applied Biosystems 3730XL (Applied Biosystems, Foster City, California, United States) high throughput capillary sequencer according to the GENEWIZ SOP at GENEWIZ, Inc. (South Plainfield, New Jersey, United States).

The newly obtained and retrieved based the recently published studies on Diatrypaceae (Trouillas et al. 2010, 2011, Grassi et al. 2014, Thiyagaraja et al. 2019) ITS sequences (Table 1) were aligned in CLUSTAL-X2 (Thompson et al. 1997) and edited manually in MEGA-X (Kumar et al. 2018). Some characters were trimmed from both ends of the alignment to approximate the size of the obtained sequences to those included in the dataset. Phylogenetic analysis of the aligned data was performed employing maximum-likelihood (ML) and Bayesian inference (BI) analysis. Maximum likelihood analysis was executed by Randomized accelerated maximum likelihood (RAxML) method using raxmlGUI v. 2.0. A 3-parameter model with unequal base frequencies (TPM3uf) was applied with discrete gamma distribution complemented for each substitution model with four rate classes (Silvestro \& Michalak 2011). One thousand bootstrap analysis and searches for the best-scoring ML tree were executed (Stamatakis et al. 2008). Bayesian posterior probabilities (BP) were defined by Markov Chain Monte Carlo sampling (MCMC) with GTR model in MrBayes v.3.2.7 (Huelsenbeck \& Ronquist 2001). Six simultaneous Markov Chains were run for 100,000 generations. Trees were sampled every 100 generation. The first 1000 trees were discarded, and the remaining trees were used for calculating posterior probabilities in the majority rule consensus tree.

\section{Results}

\section{Morphological characterization and Taxonomy}


Index Fungorum number: IF 123583; Facesoffungi number: FoF 09536

Sexual morph: Ascostromata 0.7-1.3 mm diam., black, superficial, subglobose or ellipsoidal, carbonaceous. Ascomata 120-350 $\mu \mathrm{m}$ diam., perithecial, black, clustered, semi-immersed, ovoid, with 2-4 locules. Asci 35-45 × 8-15 $\mu \mathrm{m}(\mathrm{n}=10)$, 8-spored, thin-walled, cylindric or slightly clavate, some rounded at apex. Ascospores $8.5-10 \times 2-3.0 \mu \mathrm{m}(\mathrm{x}=9.2 \times 2.6 \mu \mathrm{m}, \mathrm{n}=50)$, numerous, light brown to brown, allantoid, aseptate, slightly curved, smooth-walled, some with guttules.

Table 1 Fungal taxa with GenBank accession numbers of ITS sequences used in phylogenetic analyses. The strains and GenBank accession numbers of newly generated sequences from this study are in black bold

\begin{tabular}{lll}
\hline Taxon & Strain & $\begin{array}{l}\text { GenBank Accession Numbers } \\
\text { of ITS Sequences }\end{array}$ \\
\hline Allocryptovalsa rabenhorstii & WA07CO & HQ692620 \\
Allocryptovalsa rabenhorstii & WA08CB & HQ692619 \\
Anthostoma decipiens & IPVFW349 & AM399021 \\
Anthostoma decipiens & JL567 & JN975370 \\
Cryptosphaeria ligniota & CBS 273.87 & KT425233 \\
Cryptosphaeria pullmanensis & HBPF24 & KT425202 \\
Cryptosphaeria pullmanensis & ATCC 52655 & KT425235 \\
Cryptosphaeria subcutanea & DSUB100A & KT425189 \\
Cryptosphaeria subcutanea & CBS 240.87 & KT425232 \\
Cryptovalsa ampelina & A001 & GQ293901 \\
Cryptovalsa ampelina & DRO101 & GQ293902 \\
Eutypella citricola & HVVIT07 & HQ692579 \\
Eutypella citricola & HVGRF01 & HQ692589 \\
Eutypella vitis & UCD2484TX & FJ790854 \\
Eutypella vitis & 59 & KU320620 \\
Eutypella vitis & EI-13-ON & MW145141 \\
Eutypella vitis & EI-109-ON & MW145154 \\
Peroneutypa alsophila & EL58C & AJ302467 \\
Peroneutypa diminutispora & MFLUCC 17-2144 & MG873479 \\
Peroneutypa kochiana & EL53M & AJ302462 \\
Peroneutypa rubiformis & MFLUCC 17-2142 & MG873477 \\
Peroneutypa scoparia & MFLUCC 11-0478 & KU940151 \\
Quaternaria quaternate & GNF13 & KR605645 \\
Quaternaria quaternate & CBS 278.87 & AJ302469 \\
Xylaria hypoxylon & CBS 122620 & AM993141 \\
\hline
\end{tabular}

Culture characteristics - Colonies on MEA reach $5 \mathrm{~cm}$ diam. after 7 days of growth at room temperature in the dark, irregular, slightly raised, cottony, white, becoming beige, margin rough.

Material examined - Canada, Ontario, Niagara Region: EI-13-ON, on dying branches of Fagus grandifolia, $43^{\circ} 11^{\prime} 59.9^{\prime \prime} \mathrm{N} 79^{\circ} 13 ' 37.6^{\prime \prime} \mathrm{W}, 14.05 .2020$ (BILAS 51392); EI-21-ON, on dying twigs of Syringa reticulata, 43¹3'12.3"N 79¹3'35.7"W, 26.05.2020 (BILAS 51393); EI-109-ON, on dying branches of Fraxinus pennsylvanica, $43^{\circ} 05^{\prime} 55.2^{\prime \prime} \mathrm{N} 79^{\circ} 16^{\prime} 15.5^{\prime \prime} \mathrm{W}, 22.06 .2020$ (BILAS 51394).

\section{Phylogenetic analyses}

The dataset included the representatives of the family Diatrypaceae and the strains obtained from the study. Based on BLASTn search of the NCBI database using ITS sequences for both EI13-ON (MW145141) and EI-109-ON (MW145154), the top hits were E. vitis specimens collected in USA [GenBank KU320620; Identities = 579/581(99\%), Gaps = 0/581(0\%)], [GenBank AY462566; Identities = 579/581(99\%), Gaps = 0/581(0\%)], [GenBank FJ790854; Identities = 562/563(99\%), Gaps = 0/563(0\%)]. 
The RAxML and Bayesian inference analysis showed the similar tree topologies. The tree with the highest $\log$ likelihood (-3331.95) is shown in Fig. 2. The new strains from the Niagara Region, Southern Ontario, Canada were grouped with E. vitis specimens from USA and formed a distinct clade with high bootstrap support values (ML/BP=95/1.00).

\section{Discussion}

Eutypa dieback in Canada on Vitis spp. have been previously detected in vineyards surveyed in Okanagan Valley, Vancouver and Gulf Islands and Lower Mainland during the 2011 growing season; the causal agents were identified as E. lata, Eutypa flavovirens and Eutypa laevata (O'Gorman et al. 2013). E. vitis was not found in Canada, however, this species was isolated from diseased grapevines (Vitis labrusca and V. vinifera) with the Eutypa dieback symptoms in several states of USA (Farr et al. 1989, Jordan \& Schilder 2005, Vasilyeva \& Stephenson 2006, ÚrbezTorres et al. 2009, Jayawadena et al. 2018). This study firstly reports E. vitis on multiply tree hosts (Fagus grandifolia, Fraxinus pennsylvanica and Syringa reticulata) in the Niagara region of Southern Ontario, Canada. The pathogen species identity was confirmed by both morphological identification and phylogenetic analyses of ITS gene region.
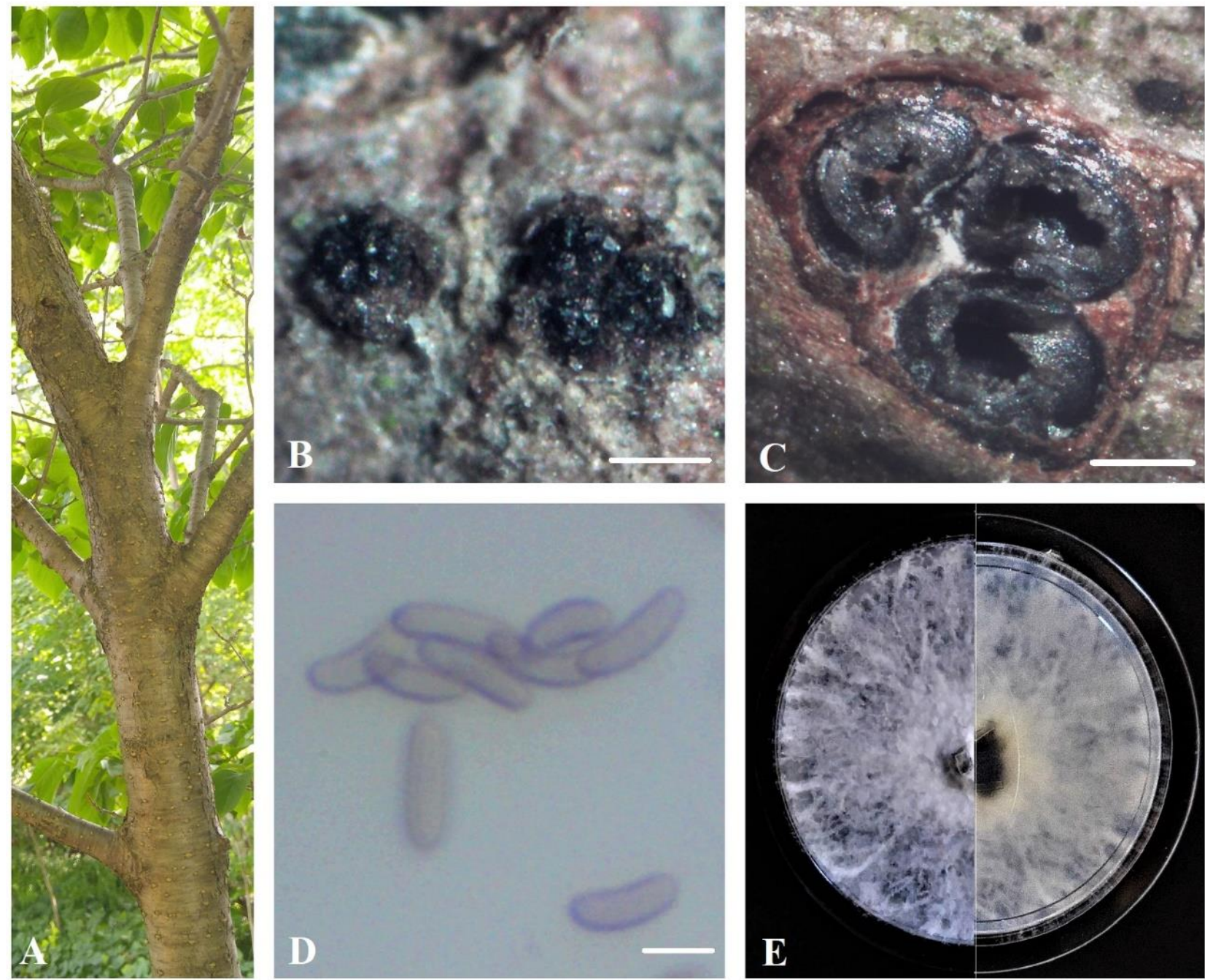

Fig. 1 - A Eutypa dieback symptoms on Syringa reticulata. B Stromata. C Transverse section through stroma. D Ascospores. E Seven-day-old culture on MEA. Scale bars: B $=0.5 \mathrm{~mm}, \mathrm{C}=100$ $\mu \mathrm{m}, \mathrm{D}=5 \mu \mathrm{m}$.

According to many researchers, there are two main morphotypes within E. vitis: the first one has shorter ascospores, up to $10.5 \mu \mathrm{m}$ long (Rappaz 1987), while the second one is characterized by 
larger ascospores with an average length of more than $10 \mu \mathrm{m}$, sometimes up to $14 \mu \mathrm{m}$ long (Ellis \& Everhart 1892, Glawe \& Jacobs 1987, Vasilyeva \& Stephenson 2006). Our isolates from Canada represent the morphotype with the shorter ascospores $(8.5-10 \mu \mathrm{m})$. The low virulence of $E$. vitis in the USA was confirmed based on the results of the pathogenicity tests controlled in the laboratory over a 28-day period (Úrbez-Torres et al. 2009). It is known E. lata slowly colonizes wood while the fungus appears to be a highly virulent pathogen on grapevines (Moller \& Kasimatis 1981). Therefore, we can assume that a pathogenicity of diatrypaceous fungi (including E. vitis) has been still underestimated. That can be a critical factor in the field conditions when trees are more likely to be stressed. More surveys are needed to find out if $E$. vitis has infected grapevines grown in the Niagara region of Southern Ontario. The ability of E. vitis to infect several alternate hosts can contribute to faster and wider spread of the fungus across vineyards in Canada.

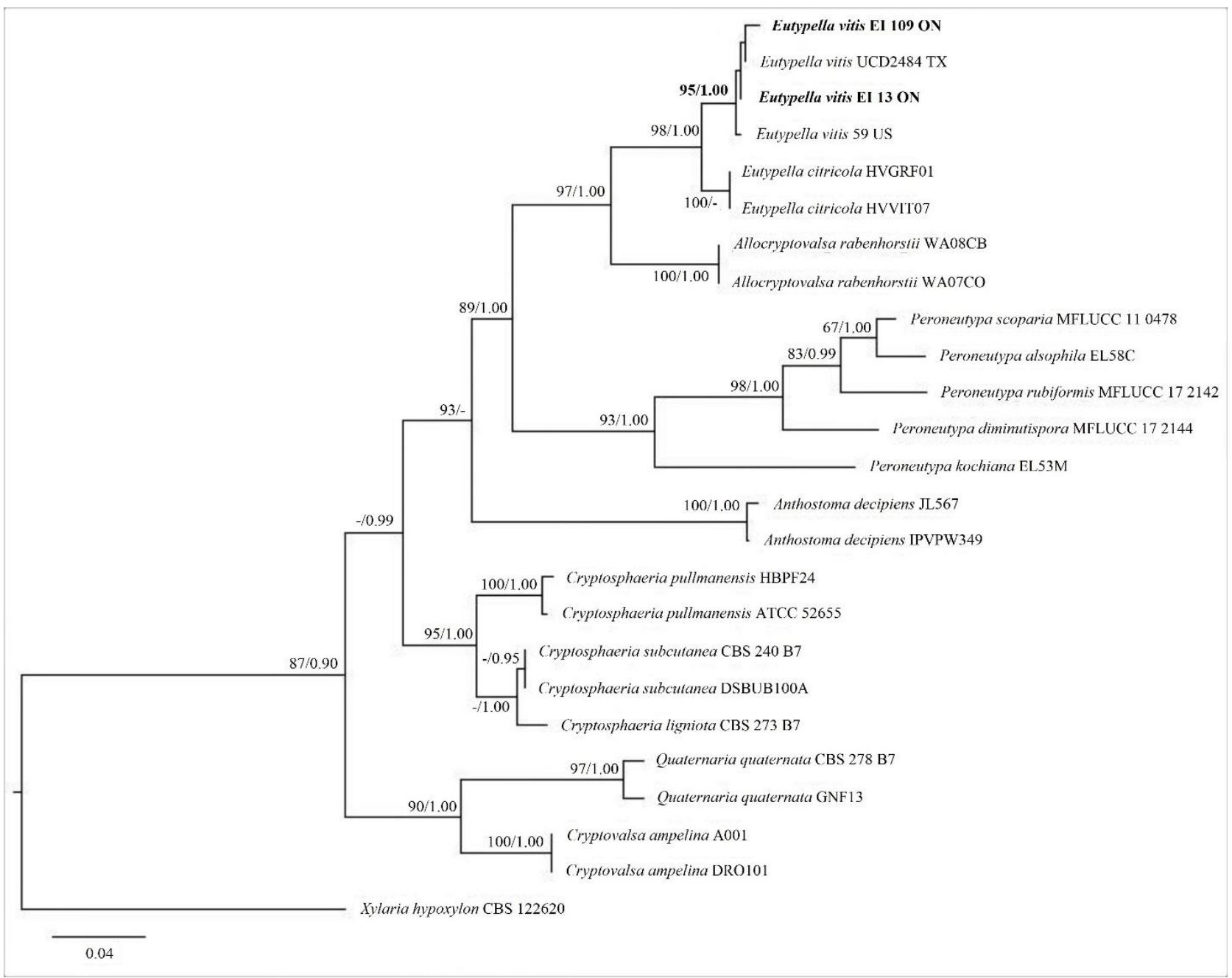

Fig. 2 - Phylogram generated from the best scoring RAxML tree based on ITS sequence data. Bootstrap support values for $\mathrm{ML} \geq 60 \%$, and Bayesian posterior probabilities (BP) $\geq 0.90$ are given as ML/BP above or below nodes. Xylaria hypoxylon (CBS 122620) is used as outgroup. The specimens found in this study are in black bold.

\section{References}

Carter MV. 1991 - The status of Eutypa lata as a pathogen. Monograph, hytopathological paper 32. Commonwealth Agric. Bureau, International Mycological Inst., Oxon, UK.

Catal M, Jordan SA, Butterworth SC, Schilder AMC. 2007 - Detection of Eutypa lata and Eutypella vitis in grapevine by nested multiplex polymerase chain reaction. Phytopathology 97, 737-747. Doi 10.1094/PHYTO-97-6-0737 
Ellis JB, Everhart BM. 1892 - The North American Pyrenomycetes. Newfield, 793 p.

Farr DF, Bills GF, Chamuris GF, Rossman AY. 1989 - Fungi on plants and plant products in the United States. St. Paul: APS Press, 1251 p.

Firoozjah MJ, Mohammadi H, Banihashemi Z. 2015 - First report of Eutypella vitis associated with persimmon trees in Iran. Disease Notes. 99, 1181. Doi 10.1094/PDIS-01-15-0013-PDN

Glawe DA, Jacobs KA. 1987 - Taxonomic notes on Eutypella vitis, Cryptosphaeria populina, and Diatrype stigma. Mycologia 79: 135-139. Doi 10.1080/00275514.1987.12025379

Grassi E, Belen Pildain M, Levin L, Carmaran C. 2014 - Studies in Diatrypaceae: the new species Eutypa microasca and investigation of ligninolytic enzyme production. Sydowia 66, 99-114. Doi 10.12905/0380.sydowia66(1)2014-0099

Huelsenbeck JP, Ronquist F. 2001 - MRBAYES: Bayesian inference of phylogenetic trees. Bioinformatics 17, 754-755. Doi 10.1093/bioinformatics/17.8.754

Jayasiri SC, Hyde KD, Ariyawansa HA, Bhat J et al. 2015 - The Faces of Fungi database: fungal names linked with morphology, phylogeny and human impacts. Fungal Diversity 74(1): 3 18. Doi 10.1007/s13225-015-0351-8.

Jayawadena RS, Purahong W, Zhang W, Wubet T et al. 2018 - Biodiversity of fungi on Vitis vinifera L. revealed by traditional and high-resolution culture-independent approaches. Fungal Diversity 90, 1-84. Doi 10.1007/s13225-018-0398-4

Jordan S, Schilder A 2005 - Eutypella vitis, a potential pathogen of grapevines in Michigan. (Abstr.). Phytopathology 95, S51.

Kumar S, Stecher G, Li M, Knyaz C, Tamura K. 2018 - MEGA X: Molecular Evolutionary Genetics Analysis across computing platforms. Molecular Biology and Evolution 35, $1547-$ 1549. Doi 10.1093/molbev/msy096

Luque J, Martos S, Phillips AJL. 2005 - Botryosphaeria viticola sp. nov. on grapevines: A new species with a Dothiorella anamorph. Mycologia 97, 1111-1121.

Doi 10.3852/mycologia.97.5.1111

Moller WJ, Kasimatis AN. 1981 - Further evidence that Eutypa armeniacae - not Phomopsis viticola - incites dead arm symptoms on grape. Plant Dis. 65, 429-431.

Doi 10.1094/PD-65-429

O’Gorman D, Haag P, Úrbez-Torres J. 2013 - Grape Vine Trunk Disease in the Okanagan Valley. Pacific Agriculture Research Centre, Summerland BC, 47/49 https://brocku.ca/ccovi/wp-content/uploads/sites/125/O\%E2\%80\%99Gorman-2013-dna.pdf

OMAFRA. 2020 - (Ontario Ministry of Agriculture, Food and Rural Affairs). Statistics from http://www.omafra.gov.on.ca/english/stats/hort/grape.xls (Retrieved on 14 August 2020)

Phookamsak R, Norphanphoun C, Tanaka K, Dai D et al. 2015 - Towards a natural classification of Astrosphaeriella-like species; introducing Astrosphaeriellaceae and Pseudoastrosphaeriellaceae fam. nov. and Astrosphaeriellopsis, gen. nov. Fungal Diversity 74, 143-197. Doi 10.1007/s13225-015-0352-7

Rappaz F. 1987 - Taxonomie et nomenclature des Diatrypacees a asques octospores. Mycol. Helvetica 2: 285-648.

Rolshausen PE, Mahoney NE, Moulynex RJ, Gubler WD. 2006 - A reassessment of the species concept in Eutypa lata, the causal agent of Eutypa dieback of grapes. Phytopathology 96, 369-377. Doi 10.1094/PHYTO-96-0369

Silvestro D, Michalak I. 2011 - raxmlGUI: a graphical front-end for RAxML. Organisms Diversity \& Evolution 12, 335-337. Doi 10.1007/s13127-011-0056-0

Sohrabi M, Mohammadi H, Leon M, Armengol J, Banihashemi Z. 2020 - Fungal pathogens associated with branch and trunk cankers of nut crops in Iran. European Journal of Plant Pathology 157(2), 327-351. Doi 10.1007/s10658-020-01996-w

Stamatakis A, Hoover P, Rougemont J. 2008 - A rapid bootstrap algorithm for the raxml web servers. Systematic Biology 57, 758-771. Doi 10.1080/10635150802429642 
Thompson JD, Gibson TJ, Plewniak F, Jeanmougin F et al. 1997 - The Clustal-X windows interface: flexible strategies for multiple sequence alignment aided by quality analysis tools. Nucleic Acids Res 25:4876-4882. Doi 10.1093/nar/25.24.4876

Trouillas F, Gubler WD. 2004 - Identification and characterization of Eutypa leptoplaca, a new pathogen of grapevine in northern California. Mycol. Res. 108, 1195-1204.

Doi 10.1017/S0953756204000863

Trouillas FP, Pitt WM, Sosnowski MR, Huang R et al. 2011 - Taxonomy and DNA phylogeny of Diatrypaceae associated with Vitis vinifera and other woody plants in Australia. Fungal Diversity 49, 203-223. Doi 10.1007/s13225-011-0094-0

Trouillas FP, Úrbez-Torres JR, Gubler WD. 2010 - Diversity of diatrypaceous fungi associated with grapevine canker diseases in California. Mycologia 102, 319-336. Doi 10.3852/08-185

Thiyagaraja V, Senanayake IC, Wanasinghe DN, Karunarathna SC et al. 2019 - Phylogenetic and morphological appraisal of Diatrype lijiangensis sp. nov. (Diatrypaceae, Xylariales) from China. Asian Journal of Mycology 2, 198-208. Doi 10.5943/ajom/2/1/10

Úrbez-Torres JR, Adams P, Kamas J, Gubler WD. 2009 - Identification, incidence, and pathogenicity of fungal species associated with grapevine dieback in Texas. American Journal of Enology and Viticulture 60, 497-507.

Úrbez-Torres JR, Haag P, Bowen P, O'Gorman DT. 2014 - Grapevine trunk diseases in British Columbia: Incidence and characterization of the fungal pathogens associated with esca and Petri diseases of grapevine. Plant Dis. 98: 469-482. Doi 10.1094/ PDIS-05-13-0523-RE

Vasilyeva LN, Stephenson SL. 2006 - Pyrenomycetes of the Great Smoky Mountains National Park. III. Cryptosphaeria, Eutypa and Eutypella (Diatrypaceae). Fungal Diversity 22: 243254.

White TJ, Bruns T, Lee S, Taylor J. 1990 - Amplification and direct sequencing of fungal ribosomal RNA genes for phylogenetics. PCR protocols: A guide to methods and applications 18, 315-322. Doi 10.1016/B978-0-12-372180-8.50042-1 